\title{
Isolation and identification of a halophilic and alkaliphilic microalgal strain
}

\author{
Chenxi Liu ${ }^{1}$, Jiali Liu ${ }^{1}$, Songmiao Hu ${ }^{1}$, Xin Wang ${ }^{1}$, Xuhui Wang ${ }^{1}$, Qingjie Guan ${ }^{\text {Corresp. } 1}$ \\ ${ }^{1}$ Key Laboratory of Saline- \\ alkali Vegetation Ecology Restoration (SAVER), Ministry of Education, Alkali Soil Natural Environmental Science Center (ASNESC), Northeast Forest \\ University, Harbin, China \\ Corresponding Author: Qingjie Guan \\ Email address: guanqingjie@nefu.edu.cn
}

Halophilic and alkaliphilic microalgal strain SAE1 was isolated from the saline-alkaline soil of Songnen Plain of Northeast China. Morphological observation revealed that SAE1 has a simple cellular structure, single cell, spherical, diameter of 4 6um, cell wall of about 0.22 um thick, two chloroplasts and one nucleus.Analysis of the phylogenetic tree constructed by $18 \mathrm{~S}$ sequence homology suggests that SAE1 is highly homologous to Nannochloris sp. BLD-15, with only four base substitutions in the homologous region. SAE1 was initially considered as Nannochloris sp. Analysis of the halophilic and alkaliphilic characteristics of SAE1 indicates that it can grow under $1 \mathrm{M} \mathrm{NaHCO}_{3}$ and $\mathrm{NaCl}$ concentrations, with optimal growth under $400 \mathrm{mM} \mathrm{NaHCO}_{3}$ and $200 \mathrm{mM} \mathrm{NaCl}$. The intracellular ultrastructure of SAEl significantly changed after $\mathrm{NaCl}$ and $\mathrm{NaHCO}_{3}$ treatments. A large number of starch grains accumulated after treatment with $400 \mathrm{mM}$ $\mathrm{NaHCO}_{3}$ in cells, but few were found after treatment with $200 \mathrm{mM} \mathrm{NaCl}$ and none in the living condition without treatment. We conjectured that one of the metabolic characteristics of alkaliphilic $\left(\mathrm{NaHCO}_{3}\right)$ microalga SAE1 is the formation of massive starch grains, which induce glycerol anabolism and increase osmotic pressure, thereby enhancing its ability to resist saline-sodic conditions. This feature of alkaliphilic $\left(\mathrm{NaHCO}_{3}\right)$ microalga SAE1 contributes to its growth in the carbonate soil of Songnen Plain. 
5 Chenxi Liu ${ }^{1}$, Jiali Liu ${ }^{1}$, Songmiao $\mathrm{Hu}^{1}$, Xin Wang ${ }^{1}$, Xuhui Wang ${ }^{1}$, Qingjie Guan ${ }^{1 *}$

$6{ }^{1}$ Key Laboratory of Saline-alkali Vegetation Ecology Restoration (SAVER), Ministry of Educati

7 on, Alkali Soil Natural Environmental Science Center (ASNESC), Northeast Forestry University

8 , No.26 hexing Road, Xiangfang District, Harbin, China

9 Corresponding Author:

10 Qingjie Guan

11 guanqingjie@,nefu.edu.cn 


\section{Abstract}

Halophilic and alkaliphilic microalgal strain SAE1 was isolated from the saline-alkaline soil of Songnen Plain of Northeast China. Morphological observation revealed that SAE1 has a simple cellular structure, single cell, spherical, diameter of 4 6um, cell wall of about $0.22 \mathrm{um}$ thick, two chloroplasts and one nucleus.Analysis of the phylogenetic tree constructed by $18 \mathrm{~S}$ sequence homology suggests that SAE1 is highly homologous to Nannochloris sp. BLD-15, with only four base substitutions in the homologous region. SAE1 was initially considered as Nannochloris sp. Analysis of the halophilic and alkaliphilic characteristics of SAE1 indicates that it can grow under

$1 \mathrm{M} \mathrm{NaHCO}_{3}$ and $\mathrm{NaCl}$ concentrations, with optimal growth under $400 \mathrm{mM} \mathrm{NaHCO}$ and $200 \mathrm{mM}$ $\mathrm{NaCl}$. The intracellular ultrastructure of SAE1 significantly changed after $\mathrm{NaCl}$ and $\mathrm{NaHCO}_{3}$ treatments. A large number of starch grains accumulated after treatment with $400 \mathrm{mM} \mathrm{NaHCO}$ in cells, but few were found after treatment with $200 \mathrm{mM} \mathrm{NaCl}$ and none in the living condition without treatment. We conjectured that one of the metabolic characteristics of alkaliphilic $\left(\mathrm{NaHCO}_{3}\right)$ microalga SAE1 is the formation of massive starch grains, which induce glycerol anabolism and increase osmotic pressure, thereby enhancing its ability to resist saline-sodic conditions. This feature of alkaliphilic $\left(\mathrm{NaHCO}_{3}\right)$ microalga SAE1 contributes to its growth in the carbonate soil of Songnen Plain. 


\section{Introduction}

41 Current soil environment is threatened by salinization (Ruppel,Franken\&Witzel,2013; Navarro-

42 Torre et al.,2016). Introducing heterologous genes to plants during cultivation is a new strategy to

43 adapt to extreme environments, such as saline-alkali environments. Isolating germplasm or genetic

44 resources is the primary prerequisite in this technique (Ohki et al.,2011;Wei, Takano\&Liu,2012).

45 Algae are extensively distributed in extreme environments, such as deserts, craters, salt lakes, and 46 polar region.(Brock,1975;Carson and Brown,1978;Rayburn,Mack \& Metting,1982;Hu et al.,2003; Khalil et al.,2010). Therefore, the exploration of algal germplasm resources has been a new research focus. Some algae can grow under extreme conditions. For instance, Dunaliella bardawil and Aphanothece halophytica can survive high-concentration NaCl (Brock, 1975;Khalil et al.,2010), and Microcoleus, Scytonema, Schizothrix, Desmococcus, and Stichococcus can survive arid and semi-arid deserts (Hu et al.,2003). However, the saline soil of the Songnen Plain of Northeast China consists of $\mathrm{NaHCO}_{3}$ and $\mathrm{Na}_{2} \mathrm{CO}_{3}$ with $\mathrm{pH}$ values ranging from 9.0 to 10.5 , and reports on algae growing under carbonate conditions are rare. Thus, in the present study, we had isolated and purified a halophilic and alkaliphilic microalgal strain from extreme carbonate soil (alkali spot). The isolated microalga was subjected to morphological, molecular and halophilic

$\left(\mathrm{NaCl}, \mathrm{NaHCO}_{3}\right)$ characterization. This halophilic and alkaliphilic microalga can be used to 
57 improve carbonate soil and explore resistance genes.

58

\section{Materials and methods}

Soil samples of alkali spot from the saline Songnen Plain of Northeast China (Anda City) were collected. The algae were isolated using the streak plate method. A loop of algae was streaked in BBM solid medium for inverted culture. When the algal colonies grew,they were again streaked until single colonies appeared on the plate upon microscopic examination. The algal species was stored in the Alkali Soil Natural Environmental Science Center of Northeast Forestry University.

\subsection{Methods}

\subsubsection{The culture of microalgae}

The microalga was cultured on improved BBM medium (Fabregas et al.,2000) consisting of $0.250 \mathrm{~g} / \mathrm{L} \mathrm{NaNO} \mathrm{Na}_{3}, 0.025 \mathrm{~g} / \mathrm{L} \mathrm{NaCl}, 0.075 \mathrm{~g} / \mathrm{L} \mathrm{K}_{2} \mathrm{HPO}_{4}, 0.175 \mathrm{~g} / \mathrm{L} \mathrm{KH}_{2} \mathrm{PO}_{4}, 0.011 \mathrm{~g} / \mathrm{L} \mathrm{H}_{3} \mathrm{BO}_{3}$, $0.050 \mathrm{~g} / \mathrm{L}$ EDTA, $0.031 \mathrm{~g} / \mathrm{L} \mathrm{KOH}, 0.490 \mathrm{mg} / \mathrm{L} \mathrm{Co}\left(\mathrm{NO}_{3}\right)_{2} \cdot 6 \mathrm{H}_{2} \mathrm{O}, 1 \mathrm{mg} / \mathrm{L} \mathrm{CuSO} \mathrm{Cu}_{4}, 1.440 \mathrm{mg} / \mathrm{L}$ $\mathrm{MnCl}_{2} \cdot 4 \mathrm{H}_{2} \mathrm{O}, 8.820 \mathrm{mg} / \mathrm{L} \mathrm{ZnSO} \cdot 7 \mathrm{H}_{2} \mathrm{O}, 0.710 \mathrm{mg} / \mathrm{L} \mathrm{MoO} 3,0.075 \mathrm{~g} / \mathrm{L} \mathrm{MgSO} \cdot 7 \mathrm{H}_{2} \mathrm{O}, 0.025 \mathrm{~g} / \mathrm{L}$ $\mathrm{CaCl}_{2} \cdot 2 \mathrm{H}_{2} \mathrm{O}, 5 \mathrm{mg} / \mathrm{L} \mathrm{FeSO}_{4} \cdot 7 \mathrm{H}_{2} \mathrm{O}$, and $\mathrm{KOH}$ adjusted $\mathrm{pH}$ 8.0.

\subsubsection{Morphological observations}

Optical microscopy The algal cells cultured to the logarithmic growth phase were visualized using optical microscopy. Under $4000 \times$ the total magnification, the morphology of intravital algal cells were directly observed.

\section{Transmission electron microscopy thin sectioning and observation Algal cells were collected}


76 by centrifugation, and $3 \%$ glutaraldehyde fixative $(0.1 \mathrm{~mol} / \mathrm{L} \mathrm{PBS}, \mathrm{pH} 7.2)$ that was 20 times the

77 volume of algal cells was added and fixed for more than $24 \mathrm{~h}$ at room temperature. After being 78 rinsed by $0.1 \mathrm{~mol} / \mathrm{L} \mathrm{PBS}$, the algal cells were treated with $1 \%$ osmic acid-fixed liquid for $4 \mathrm{~h}$ at 79 room temperature $(0.1 \mathrm{~mol} / \mathrm{L} \mathrm{PBS}, \mathrm{pH} 7.2)$, dehydrated with graded ethanol at increasing 80 concentrations $\left(50 \%, 15^{\prime} \times 1 ; 70 \%, 15^{\prime} \times 1 ; 80 \%, 15^{\prime} \times 1 ; 90 \%, 15^{\prime} \times 1\right.$; and $100 \%$,

$811^{\prime} \times 2$ ), soaked and embedded with Spurr, and then polymerized overnight at $80{ }^{\circ} \mathrm{C}$. The cells 82 were later sliced with ultramicrotome LKB-1, double stained with uranyl acetate and lead citrate, 83 observed, and then photographed under an electron microscope (Hitachi-7650).

\subsubsection{DNA extraction and analysis of sequence data}

Improved CTAB method (Porebski,Bailey\&Baum,1997) was employed to extract the genomic DNA of microalga SAE1. Algal cells at the exponential growth phase in suspension liquid were collected by centrifuging at 10,000 rpm for $5 \mathrm{~min}$, grounded to powder in liquid nitrogen with mortar and pestle. The cells were added into a preheated $2 \times \mathrm{CTAB}$ solution at $65^{\circ} \mathrm{C}$ and incubated in bathtub at $65{ }^{\circ} \mathrm{C}$ for $30 \mathrm{~min}$. After cooling to room temperature, it was added with equivalent chloroform:isoamyl alcohol (24:1), and the obtained solution was centrifuged at $12,000 \mathrm{rpm}, 4{ }^{\circ} \mathrm{C}$ for $10 \mathrm{~min}$. The supernatant was placed into a new centrifuge tube, to which equivalent isopropanol was added. The mixture was deposited at $-20{ }^{\circ} \mathrm{C}$ for $30 \mathrm{~min}$ and then centrifuged at 12,000 rpm, 4 ${ }^{\circ} \mathrm{C}$ for $10 \mathrm{~min}$. The supernatant fluid was discarded, and the rest was rinsed twice with $75 \%$ ethanol and then added with deionized water containing RNAase to dissolve DNA after drying at room temperature.

We amplified the partial $18 \mathrm{~S}$ rRNA gene regions using the primer sets $18 \mathrm{SF}$ : $5^{\prime}$ - 
97

98

99

100

101

102

103

\section{AACCTGGTTGATCCTGCCAGT-3' and 18SR:5' -TTGATCCTTCTGCAGGTTCACC-3'}

(Katana et al.,2001). The PCR reaction conditions were as follows: 5 min at $94{ }^{\circ} \mathrm{C}, 30$ cycles for $1 \mathrm{~min}$ at $94{ }^{\circ} \mathrm{C}, 1.5 \mathrm{~min}$ at $55{ }^{\circ} \mathrm{C}, 2 \mathrm{~min}$ at $72{ }^{\circ} \mathrm{C}$, and a final extension for $10 \mathrm{~min}$ at $72{ }^{\circ} \mathrm{C}$. Then, agarose gel electrophoresis and recovery of DNA were performed. We sequenced DNA to BGI(Beijing Genomics Institute, China). We analyzed the sequences by a similarity search using BLAST software (http://blast.ncbi.nlm.nih.gov/Blast.cgi). We aligned multiple sequences using the ClustalX 1.8 program. 18S rRNA of the microalgae was sequenced, and its relative genetic distance was calculated with MEGA5.0 software. A phylogenetic tree was constructed with the maximum likelihood method (UPGMA), To test the confidence of the tree topologies, we performed bootstrap analyses for maximum likelihood method (1000 replicates).

\subsubsection{Analysis of the halophilic and alkaliphilic features of the microalga}

A $1 \mathrm{~mL}$ aliquot of the microalga SAE1 solution at the logarithmic phase was added into sterile BBM medium. Then, filter-sterilized $\mathrm{NaCl}$ and $\mathrm{NaHCO}_{3}$ solution were added. The final concentrations of $\mathrm{NaCl}$ were successively $0,100,200,400,600,800$, and $1000 \mathrm{mmol} / \mathrm{L}$, whereas those of $\mathrm{NaHCO}_{3}$ were $0,50,100,200,300,400$, and $500 \mathrm{mmol} / \mathrm{L}$. After mixing, the solution was cultured at $25^{\circ} \mathrm{C}$ under a 16:8 h L:D cycle condition, shook several times every day, also observed and recorded their growth after $14 \mathrm{~h}$. The value of $\mathrm{OD}_{\lambda=700}$ was measured by a spectrophotometer.

Monoclonal microalgae on the plate were picked for culture onto BBM liquid medium at $25{ }^{\circ} \mathrm{C}$ under a 16:8 $\mathrm{h} \mathrm{L}: \mathrm{D}$ cycle condition. When they grew to the logarithmic phase, $\mathrm{NaCl}$ at the final concentration of $200 \mathrm{mmol} / \mathrm{L}$ and $\mathrm{NaHCO}_{3}$ of $400 \mathrm{mmol} / \mathrm{L}$ were added to stress culture for 2 days. The cellular structure of the microalga was observed via transmission electron microscopy (TEM), 
118 and the slice-making method was performed as previously described.

119

120

121

122

123

124

125

126

127

128

129

130

131

132

133

134

135

136

\section{Results}

\subsection{Morphology of microalga SAE1}

Single colonies that were isolated and purified by the streak plate method with alkali spot soil solution were recorded and preserved as microalga SAE1. The single algal cells that appeared green in good growth state were taken for culture in liquid. When the concentration of SAE1 was comparatively low, the solution appeared light green. As the concentration grew, the green color darkened. TEM observation indicates that SAE1 has a simple cellular structure (Figure 1). It is spherical or nearly spherical with a diameter of 4-6 $\mu \mathrm{m}$ and a cell wall thickness of $0.22 \mu \mathrm{m}$ and contains two chloroplasts, one nucleus, one pyrenoid, and several mitochondria, and its reproduction is through binary fission.

\subsection{Phylogenetic analysis of microalgal SAE1}

The length of the $18 \mathrm{~S}$ rRNA sequence of SAE1 microalgae after PCR amplification, electrophoresis, purification and sequencing was $1795 \mathrm{bp}$. The nucleotide sequence was submitted to GenBank. Homologous comparison with the data of GenBank showed that it has $99 \%$ similarity to Nannochloris sp. BLD-15, with only four base substitutions, and $98 \%$ similarity to Nannochloris sp. $A S$ 2-10. Homologous comparison using the phylogenetic tree (Figure 2) constructed by 
137 MEGA5.0 with the maximum likelihood method shows that SAE1 belongs to the same branch of 138 Nannochloris sp. BLD-15. Thus, microalga SAE1 was preliminary identified to be the 139 physiological race of the genus Nannochloris.

\subsection{Salt and alkaline tolerance of microalga SAE1}

142

143

\subsubsection{Growth pattern of microalga SAE1 in $\mathrm{NaCl}$ and $\mathrm{NaHCO3}$ treatments}

The growth-consistent microalgae SAE1 cells were examined for phenotype under $\mathrm{NaHCO}_{3}$ resistance stress (Figure 3-A).The green color of the algal cells darkened as the $\mathrm{NaHCO}_{3}$ concentration in the medium increased, indicating that cell growth significantly accelerated. The microalgal cells had slower growth rate in the medium with $\mathrm{NaCl}$ than in that with $\mathrm{NaHCO}_{3}$, but appropriate amount of $\mathrm{NaCl}$ still promoted the growth of the microalgae. When the $\mathrm{NaCl}$ concentration was $200 \mathrm{mmol} / \mathrm{L}$, the phenotypic observation indicated that green color darkened (Figure 3-B). When the $\mathrm{NaHCO}_{3}$ concentration was $400 \mathrm{mmol} / \mathrm{L}$, the growth rate was the greatest (Figure 3-C), so was the value of $\mathrm{OD}_{\lambda=700}$ detected by a UV spectrophotometer, indicating the peak of the exponential growth phase. When the $\mathrm{NaCl}$ concentration was $200 \mathrm{mmol} / \mathrm{L}$, the value of $\mathrm{OD}_{\lambda=700}$ was the greatest, the growth rate of the microalga reached the maximum (Figure 3-D). The cells of SAE1 still survived under the treatment of $1 \mathrm{M} \mathrm{NaCl}$. 
156

157

158

159

160

161

162

163

164

165

166

167

168

169

170

171

172

173

174

175

\subsubsection{Growth pattern of microalga $\mathrm{SAE} 1$ in $\mathrm{NaCl}$ and $\mathrm{NaHCO3}$ treatments}

To further characterize the cellular structure of SAE1 that can grow in high-saline and alkaline environments, We detected by TEM that there was no starch grain in the algae cells untreated with saline and alkaline(Figure 4-A ). But only a few starch grains under $200 \mathrm{mmol} / \mathrm{L} \mathrm{NaCl}$ concentration (Figure 4-B), However a great number of starch grains was found in the cells under $400 \mathrm{mmol} / \mathrm{L} \mathrm{NaHCO}_{3}$ concentration (Figure 4-C). These results indicate that SAE1 can change intracellular dissolved matter via related metabolism in order to survive.

\section{Discussion}

Salt alga is unicellular green alga belonging to Polyblepharidaceae family. The study of molecular biology in the $21^{\text {st }}$ century steps into the era of genomics or proteomics. Liska et al. (2004) adopted 2D protein electrophoresis to compare algal cell proteins growing in low- and highsaline environments and found 76 types of protein that are induced by salt. These upregulated proteins include key enzymes in the Calvin cycle, starch metabolism, and ATP production in redox; the regulatory factors of protein synthesis and degradation; and an analog of the germ $\mathrm{Na}^{+}$ transporter pump of redox. When saline-tolerant algae migrate from a low-saline to a hypersaline environment, they increase $\mathrm{CO}_{2}$ assimilation and starch degradation by photosynthesis, rendering carbon metabolism and energy metabolism prone to glycerol synthesis. Thus, a large amount of 
176 glycerol is produced, allowing the organism to adjust to the environment (Liska et al.,2003). At

177 present, there is little research data on the microbiology of saline-alkali soils. Therefore, it is

178

179

180

181

182

183

184

185

186

187

188

189

190

191

192

193

194

195

196

necessary to study the characteristics of microorganisms in saline-alkali soils and their role in biological survival mechanisms. This will effectively improve future crop cultivation. The sodasalt microalga SAE1 isolated in this study has important theoretical and practical significance for soil ecological restoration and tolerance-related genetic engineering.

\section{Conclusions}

The halophilic and alkaliphilic microalga SAE1 isolated in this study has a thick cell wall, different from salt algae without complete cell walls. Analysis of the phylogenetic tree constructed by $18 \mathrm{~S}$ sequence homologous comparison suggests that SAE1 is highly homologous to Nannochloris sp. $B L D-15$. Given its halophilic and alkaliphilic characteristics, SAE1 can survive high $\mathrm{NaHCO}_{3}$ concentrations and high $\mathrm{pH}$ values. The amount of intracellular starch grain considerably varies when treated with $\mathrm{NaCl}$ and $\mathrm{NaHCO}_{3}$. The saline tolerance of the alga is conferred by the synthesis of abundant glycerine in cells. The primary raw material of glycerol synthesis is starch, which generates dihydroxyacetone phosphate by glycolysis, and later produces glycerine by the catalysis of $\alpha$-glycerophosphate dehydrogenase and glyceraldehyde 3-phosphate phosphatase (Goyal,2007).

One of the alkaliphilic characteristics $\left(\mathrm{NaHCO}_{3}\right)$ of microalga $\mathrm{SAE} 1$ in survival metabolism is the generation of abundant starch grains, which reveals that glycerol synthesis increases osmolality, thereby strengthening its resistance to saline-sodic conditions. The features of alkaliphilic microalga SAE1 determine that it can grow in the carbonate soil of Songnen Plain. The microalga SAE1 will be of great significance to the improvement of carbonate soil and the exploration of 
197

198

199

200

201

202

203

204

205

206

207

208

resistance genes.

\section{References}

Brock T. 1975. Salinity and the ecology of Dunaliella from the Great Salt Lake. Journal of General Microbiology 89 (2):285-292.

Carson JL and Brown RM. 1978. Studies of Hawaiian freshwater and soil algae ii. Algal colonization and succession on a dated volcanic substrate. Journal of Phycology 14 (2):171-178.

Fabregas J, Dominguez A, Regueiro M, Maseda A and Otero A. 2000. Optimization of culture medium for the continuous cultivation of the microalga Haematococcus pluvialis. Applied microbiology and biotechnology $53(5): 530-535$.

Goyal A. 2007. Osmoregulation in Dunaliella, Part II: Photosynthesis and starch contribute carbon for glycerol synthesis during a salt stress in Dunaliella tertiolecta. Plant Physiology and Biochemistry 45 (9):705-710.

Hu C, Zhang D, Huang Z and Liu Y. 2003. The vertical microdistribution of Cyanobacteria and green algae within desert crusts and the development of the algal crusts. Plant and Soil 257 (1):97-111.

Katana A, Kwiatowski J, Spalik K, Zakryś B, Szalacha E and Szymańska H. 2001. Phylogenetic position of Koliella (Chlorophyta) as inferred from nuclear and chloroplast small subunit rDNA. Journal of Phycology 37 (3):443-451.

Khalil ZI, Asker MM S, El-Sayed S and Kobbia IA. 2010. Effect of pH on growth and biochemical responses of Dunaliella bardawil and Chlorella ellipsoidea. World Journal of Microbiology and Biotechnology 26 
217 Liska AJ, Shevchenko A, Pick U and Katz A. 2004. Enhanced photosynthesis and redox energy production contribute

Porebski S, Bailey LG and Baum BR. 1997. Modification of a CTAB DNA extraction protocol for plants containing high polysaccharide and polyphenol components. Plant molecular biology reporter 15 (1):8-15.

Rayburn WR, Mack RN and Metting B. 1982. Conspicuous algal colonization of the ash from mount st. Helens. Journal of Phycology 18 (4):537-543.

Ruppel S, Franken P and Witzel K. 2013. Properties of the halophyte microbiome and their implications for plant salt tolerance. Functional Plant Biology 40(8-9): 3113-3116.

Wei S, Takano T, and Liu S. 2012. Isolation and characterization of novel bacterial taxa from extreme alkali-saline soil. World Journal of Microbiology and Biotechnology 28(5): 2147-2157. 


\section{Figure 1}

Morphology of the microalga.

(A) optical observation of single algal cells; (B and C) microalgal ultrastructure. C, chloroplasts; N, nucleus; and P is pyrenoid; and (D and E) microalgal cell division.
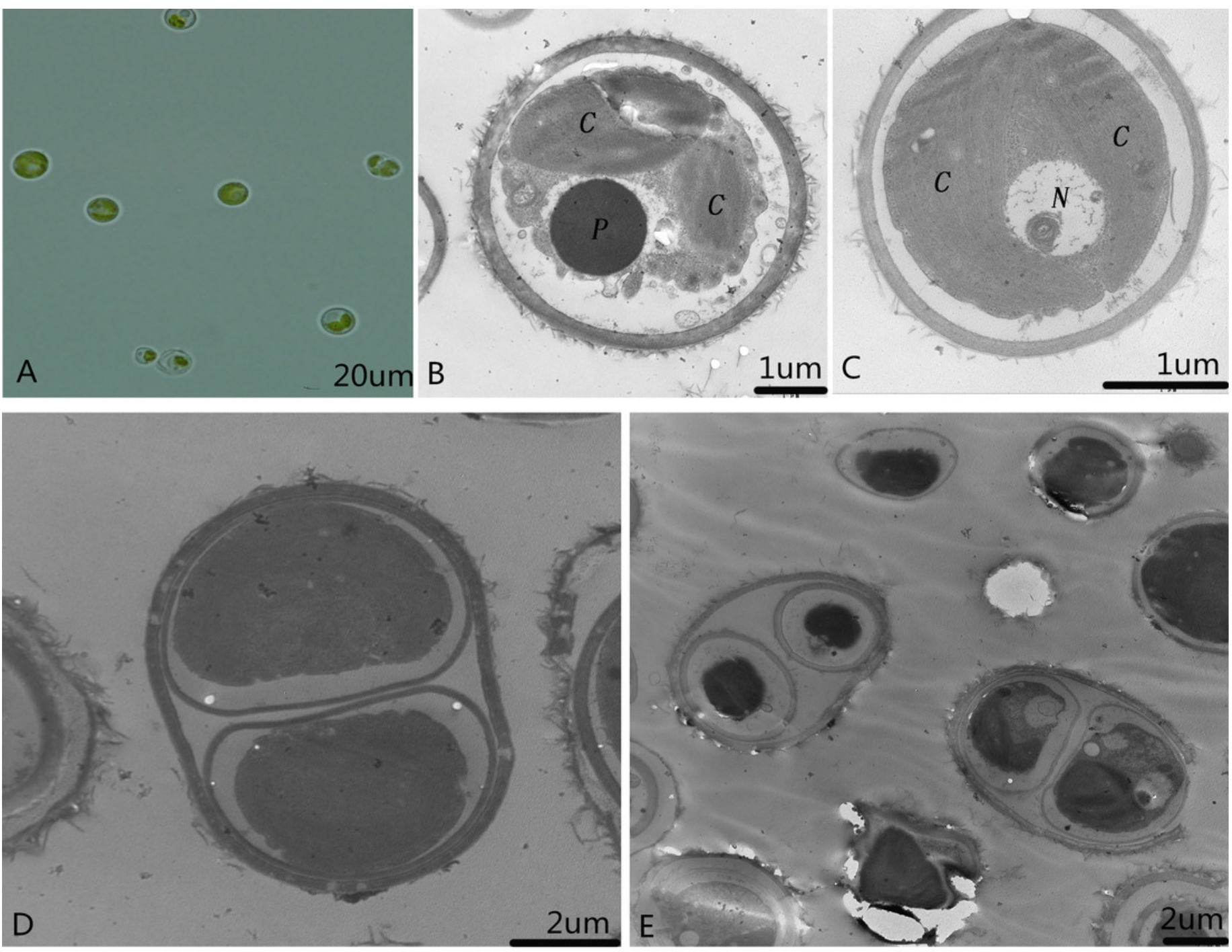
Figure 2

Molecular phylogeny of the extreme saline-alkali microalgae (SAE1) based on SSU rRNA gene sequence comparisons.

A phylogenetic tree was constructed using the neighbor-joining method. Bootstrap values were calculated 1000 times, and values below $50 \%$ were not included. Sequences were obtained from GenBank [National Center for Biotechnology Information (NCBI)]. Results identified SAE1 as Nannochloris sp. 


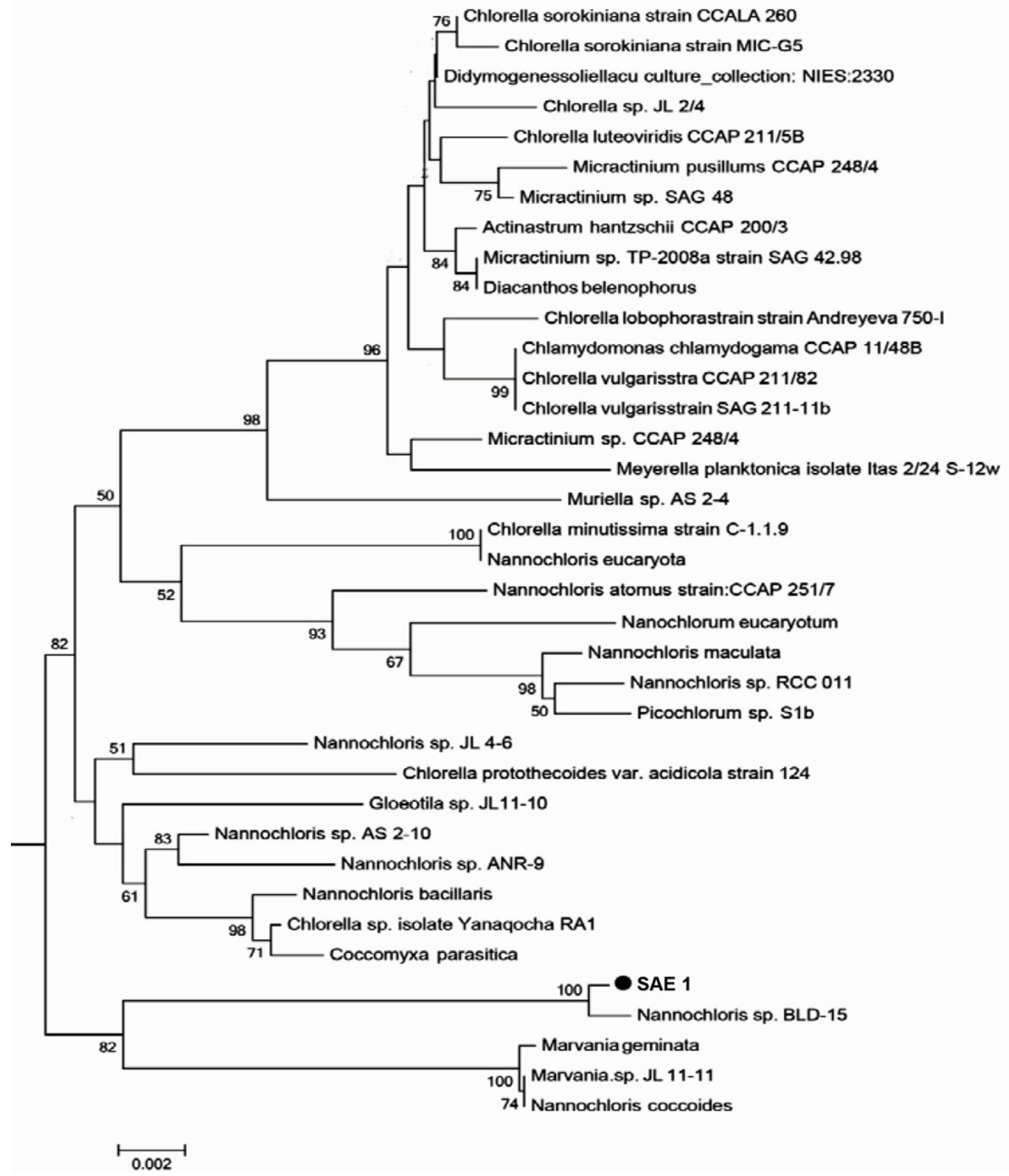




\section{Figure 3}

Growth characteristics of microalga SAE1 under $\mathrm{NaCl}$ and $\mathrm{NaHCO}_{3}$ treatments.

A. Microalgal growth under different $\mathrm{NaHCO}_{3}$ concentrations; B. microalgal growth under different $\mathrm{NaCl}$ concentrations; C. microalgal biomass under different $\mathrm{NaHCO}_{3}$ concentrations ( $\left.\mathrm{OD}_{\lambda=700}\right)$; D. microalgal biomass under different $\mathrm{NaCl}$ concentrations $\left(\mathrm{OD}_{\lambda=700}\right)$. 


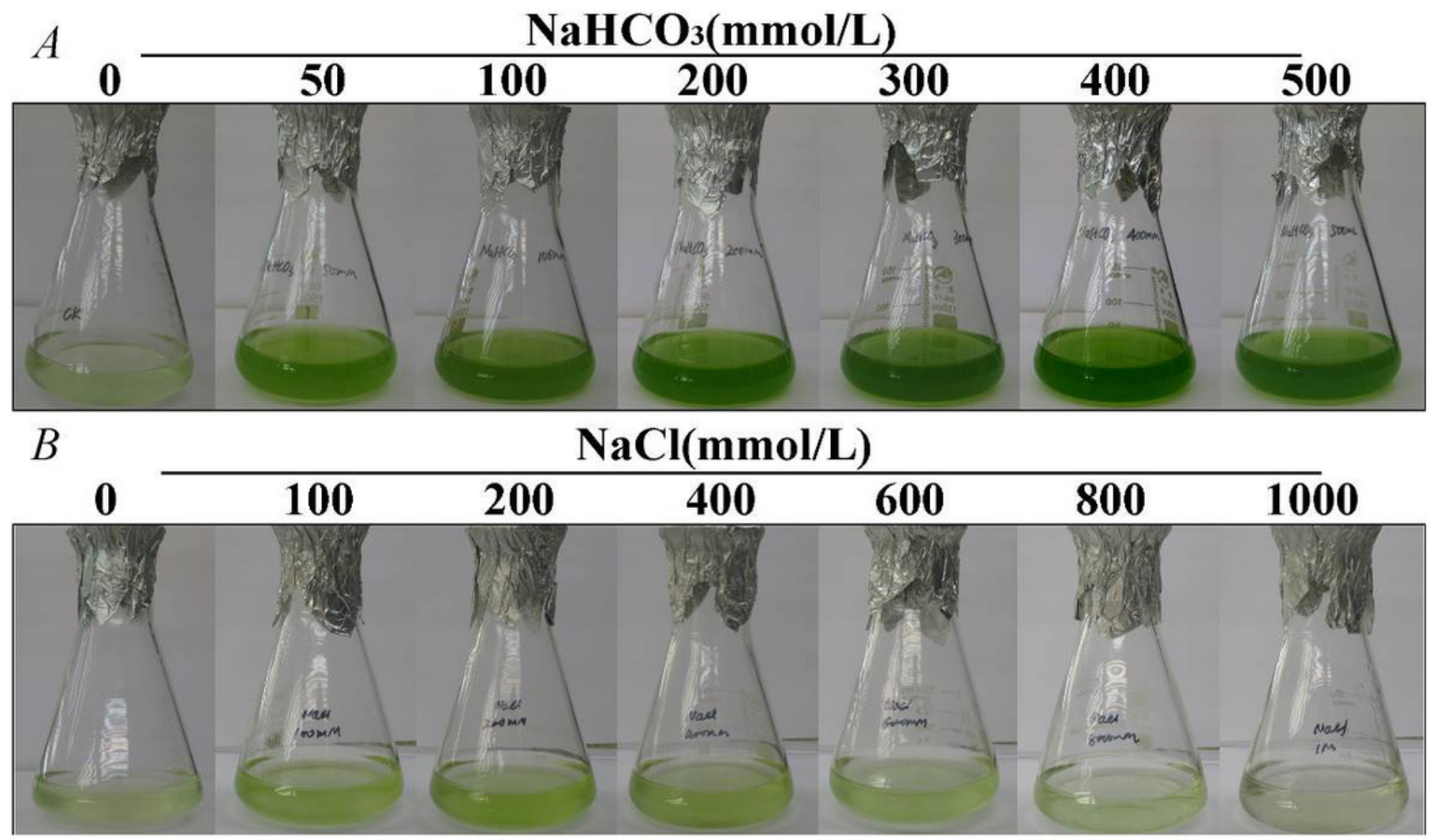

C

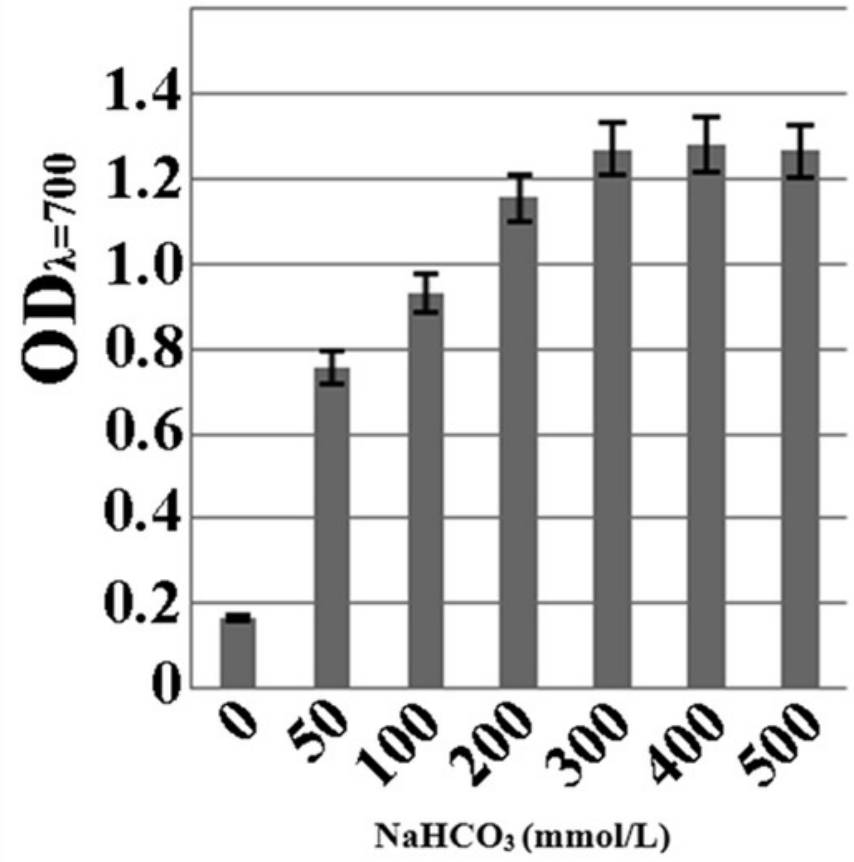

D

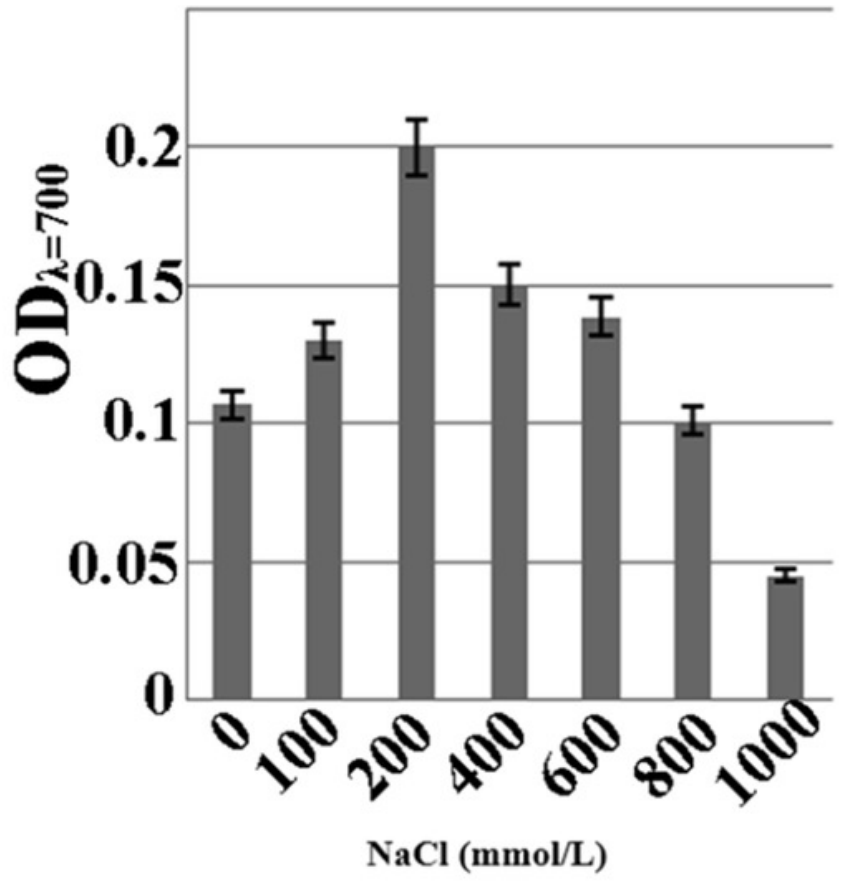




\section{Figure 4}

Changes in microalgal cellular ultrastructure under $\mathrm{NaCl}$ and $\mathrm{NaHCO}_{3}$ treatments.

A. BBM; B. BBM with $200 \mathrm{mM} \mathrm{NaCl}$; C. BBM with $400 \mathrm{mM} \mathrm{NaHCO}_{3}$. There was no starch grain in the algae cells untreated with saline and alkaline, a few starch grains appeared in three cells under $200 \mathrm{mmol} / \mathrm{L} \mathrm{NaCl}$ concentration, a great number of starch grains was found in nine cells under $400 \mathrm{mmol} / \mathrm{L} \mathrm{NaHCO}_{3}$ concentration.

*Note: Auto Gamma Correction was used for the image. This only affects the reviewing manuscript. See original source image if needed for review.
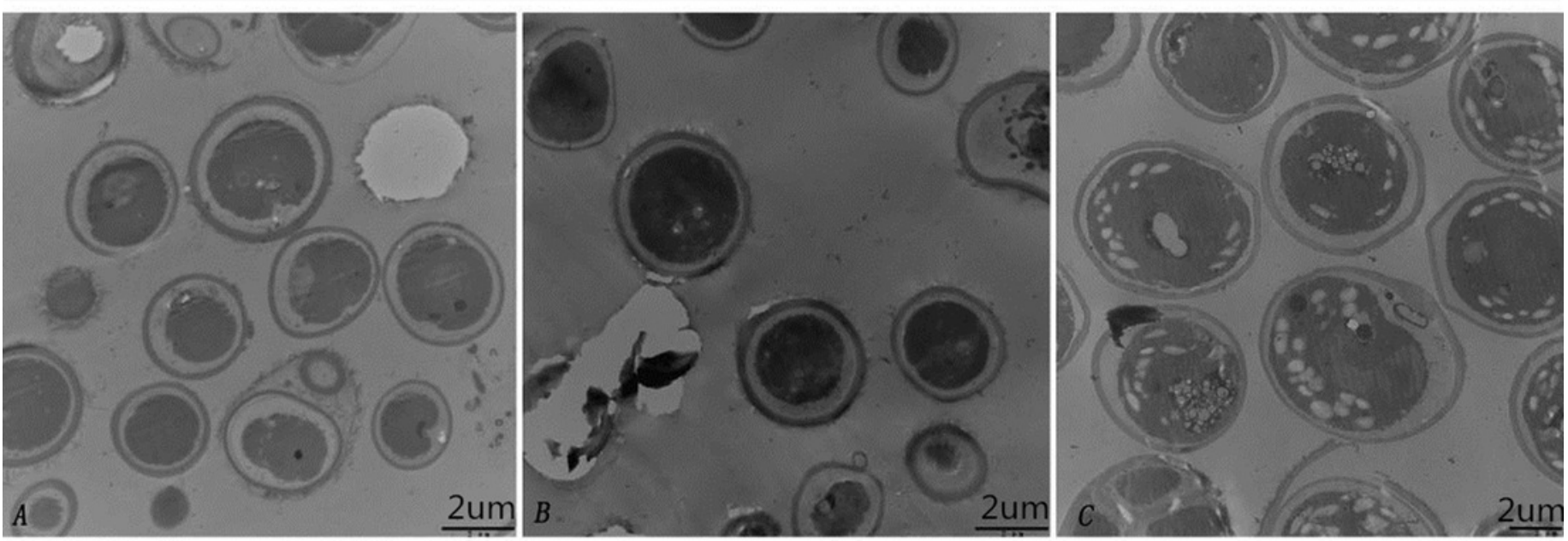